\title{
Emplacement kinematics of nepheline syenites from the Terrane Boundary Shear Zone of the Eastern Ghats Mobile Belt, west of Khariar, NW Orissa: Evidence from meso- and microstructures
}

\author{
T K Biswal*, Harish Ahuja and Himansu Sekhar Sahu \\ Indian Institute of Technology Bombay, Powai, Mumbai, 400 076, India. \\ *email: tkbiswal@geos.iitb.ac.in
}

Nepheline syenite plutons emplaced within the Terrane Boundary Shear Zone of the Eastern Ghats Mobile Belt west of Khariar in northwestern Orissa are marked by a well-developed magmatic fabric including magmatic foliation, mineral lineations, folds and S-C fabrics. The minerals in the plutons, namely microcline, orthoclase, albite, nepheline, hornblende, biotite and aegirine show, by and large, well-developed crystal faces and lack undulose extinction and dynamic recrystallization, suggesting a magmatic origin. The magmatic fabric of the plutons is concordant with a solid-state strain fabric of the surrounding mylonites that developed due to noncoaxial strain along the Terrane Boundary Shear Zone during thrusting of the Eastern Ghats Mobile Belt over the Bastar Craton. However, a small fraction of the minerals, more commonly from the periphery of the plutons, is overprinted by a solid state strain fabric similar to that of the host rock. This fabric is manifested by discrete shear fractures, along which the feldspars are deformed into ribbons, have undergone dynamic recrystallization and show undulose extinction and myrmekitic growth. The shear fractures and the magmatic foliations are mutually parallel to the C-fabric of the host mylonites. Coexistence of concordant solid state strain fabric and magmatic fabric has been interpreted as a transitional feature from magmatic state to subsolidus deformation of the plutons, while the nepheline syenite magma was solidifying from a crystal-melt mush state under a noncoaxial strain. This suggests the emplacement of the plutons synkinematic to thrusting along the Terrane Boundary Shear Zone. The isotopic data by earlier workers suggest emplacement of nepheline syenite at $1500+3 /-4 \mathrm{Ma}$, lending support for thrusting of the mobile belt over the craton around that time.

\section{Introduction}

Meso- and microscopic structures in plutons provide important clues to the kinematics of emplacement of magma. The structures may be magmatic or related to solid state deformation. While a magmatic fabric results from preferred alignment of magmatic minerals during emplacement of the melt (Bouchez et al 1990; Paterson et al 1998), a solid state fabric develops due to subsequent deformation. The nature of a magmatic fabric is controlled by various factors, namely, mode of emplacement, geometry of magma chamber, convection within the chamber, and strain during emplacement (Paterson et al 1998). In addition to these, the rheology of the magma plays an important role in fabric development. As the magma is emplaced as a crystal-melt mush, the crystal to melt ratio controls the rheology of the melt. Magma with low to medium values of crystal to melt ratio behaves as a Newtonian to visco-plastic fluid which can sustain stress and

Keywords. Nepheline syenite; Terrane Boundary Shear Zone; Eastern Ghats Mobile Belt; magmatic fabric; synkinematic emplacement. 


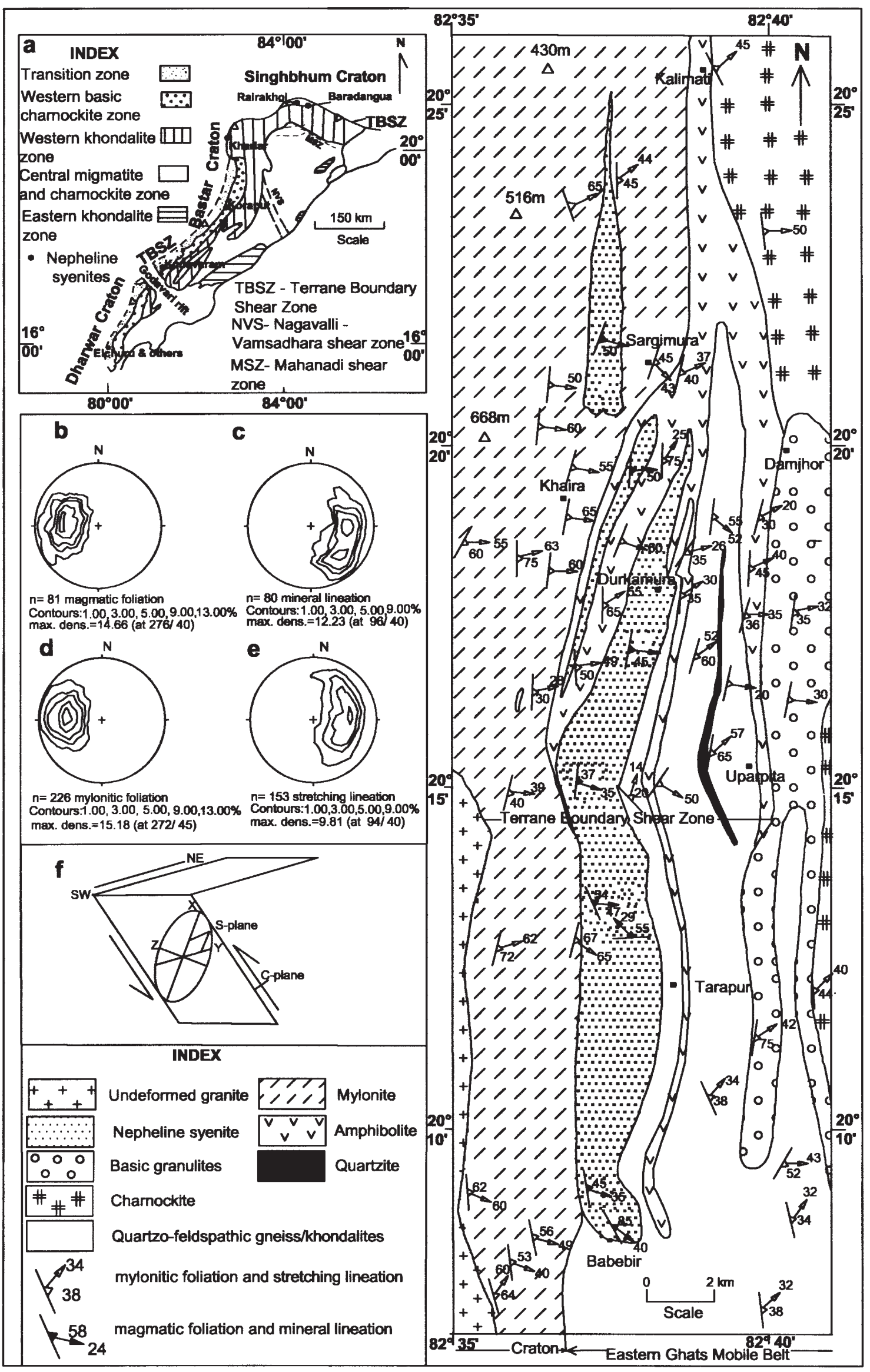

Figure 1. 
develops magmatic fabric. But with higher ratio, it behaves as a rigid body and develops fractures. Where magma is emplaced in a regional strain condition, the strain rate also controls the rheology of magma. At a lower strain rate the magma with a higher crystal to melt ratio may behave as a Newtonian fluid while the same magma behaves as a rigid body at higher strain rate.

With solidification, the rheological behavior changes; as a result the plutons record a transition from magmatic to solid state fabric. Further, a transition from magmatic to solid state fabric occurs from the centre to the margin of the plutons due to faster cooling at the margin. Magmatic fabric in conjunction with solid state fabric provides useful criteria to infer the relative timing of various orogenic events such as folding, metamorphism, shearing and magmatism in an orogenic belt. An absolute correspondence between the magmatic fabric of the plutons and the tectonic fabric of the surrounding host rock, a phenomenon known as coupling (Paterson et al 1998), is attributed to syntectonic emplacement of the plutons. In contrast a magmatic fabric that follows the outline of the plutons without bearing any relation to the host rock fabric (decoupling), characterizes pre- and late-tectonic plutons. Furthermore, a complete transition from magmatic fabric to solid state fabric, both having concordant relationship with the tectonic fabric of the host rock, is seen in syntectonic plutons (Miller and Paterson 1994). Therefore, a magmatic fabric that develops in the magma under the influence of a regional strain field has the potential to provide a "snapshot" of strain that the country rock and the plutons undergo.

The goal of this study is to test the nature of fabric preserved in nepheline syenite plutons occurring nearly $10 \mathrm{~km}$ west of Khariar in the Nawapara districts of northwestern Orissa. This fabric is developed due to the preferred alignment of minerals in alternate layers. The earlier study by Madhavan and Khurram (1989) described the fabric to be secondary in origin and related it to regional metamorphism of the host Eastern Ghats rocks. However, the present study differs from it in identifying the fabric as magmatic. Though this is the first time that this fabric is being defined as magmatic, Bose (1970), Sahu (1976) and Panda et al (1993) have made a mention about this from other areas. Further emplacement of alkaline intrusions along shear zones have also been reported from other parts of Eastern Ghats (Bhattacharya and Kar 2002).

\section{Geological setting}

The nepheline syenite plutons dealt with in this paper belong to a group of alkaline rocks (Sahu 1976; Ratnakar and Leelanandam 1989; Leelanandam 1993; Panda et al 1993; Ramakrishnan et al 1998) that have been emplaced close to the terrane margin of the Proterozoic Eastern Ghats Mobile Belt terrane (EGMB) with the surrounding cratons (Dharwar, Bastar and Singhbhum) of eastern India (figure 1a). The terrane margin to the west of Khariar, NW Orissa, is marked by a $\sim 2 \mathrm{~km}$ wide SE dipping thrust that has been designated as the Terrane Boundary Shear Zone (TBSZ) by Biswal et al (2000). In their view, the EGMB has been thrust over the Bastar Craton to NW along the thrust. The thrust zone straddles the western edge of the Eastern Ghats and the eastern edge of the Bastar Craton. Therefore, the TBSZ is represented by rock types of both the terranes. The rock types include granitic mylonite developed out of the granites and granite gneisses of the Bastar Craton, amphibolites and sheared quartzofeldspathic gneisses produced from the retrogression of the EGMB-granulites during thrusting. The amphibolite along certain sections is found to be gradational into basic granulites of the Eastern Ghats occurring outside the shear zone, thereby suggesting the Eastern Ghats affinity of the amphibolite rather than their cratonic affinity. A fold-thrust belt model has been proposed for the area with the TBSZ acting as a basal decollement (Biswal 2000). The decollement passed over a lateral ramp to the south of Khariar, which changed the trend of the TBSZ from NNE-SSW to N-S and NNW-SSE (Khariar lateral ramp, Biswal et al 2002). Tensional conditions that prevailed along the ramp structures probably facilitated the emplacement of nepheline syenite magma along the TBSZ.

The nepheline syenites close to Khariar have been previously referred to as Khariar alkaline rocks/gneisses (Srinivasachari and Balakrishnan 1973; Madhavan and Khurram 1989). Geological mapping by the present authors show the plutons as three N-S trending, closely spaced en-echelon linear bodies extending from Kalimati in the north

\section{Figure 1 caption}

Figure 1. Geological map of the Terrane Boundary Shear Zone showing occurrence of nepheline syenites, west of Khariar, Nawapara District of Orissa. Inset: (a) Geological map of Eastern Ghats Mobile Belt (after Ramakrishnan et al 1998) showing the location of nepheline syenites. Stereoplot: (b) magmatic foliation and (c) mineral lineation in nepheline syenites; (d) mylonitic foliation and (e) stretching lineation of granitic mylonites; (f) Strain ellipsoid for noncoaxial strain due to thrust-slip movement along TBSZ. 
to Babebir in the south (figure 1). These are emplaced within host rocks of mylonites, amphibolites and sheared quartzo-feldspathic gneisses (with minor pockets of khondalites) of the TBSZ. Whereas the northernmost pluton has intruded the granitic mylonite of the Bastar Craton, the central pluton occurs inside amphibolites of the EGMB and the southern pluton shares its margin with quartzofeldspathic gneisses of the EGMB to the east and mylonites of the Bastar Craton to the west, respectively. Thus the emplacement of the plutons is terrane-transgressive; however they are confined to the vicinity of the TBSZ. This suggests a deformation control on the emplacement of the nepheline syenites. Furthermore, the southernmost pluton shows folding along with the surrounding host rock near Durkamura and Uparpita. The nature of these folds will be described later.

\section{Mesostructures}

The mesoscopic structures observed in plutons and host rock are described below.

\subsection{Nepheline syenite}

The nepheline syenites show sharp intrusive contacts and at several places minor syenitic veins offshoot along the mylonitic foliations into the surrounding country rock. Because of the incursion of the melt, assimilation of granitic country rock into the nepheline syenite magma has given rise to quartz syenites near Tarapur and southwest of Kalimati. The nepheline syenite plutons carry xenoliths and schlieren of amphibolite, quartzofeldspathic gneiss and granite of variable dimensions near Durkamura. The nepheline syenites are leucocratic coarse grained rocks and become pegmatoidal in places (southernmost tip of Sargimura body). These are marked by distinct compositional layers and almost down-dip mineral lineations. At places the rocks appear more massive due to coarse-grained leucocratic segregations of feldspar and nepheline. The compositional layers are defined by thin, dark hornblende- or biotiterich layers alternating with coarse white or pinkish feldspar- and nepheline-rich layers (figures 2a, 2b). The layers are ubiquitous at all scales. The average dip of the compositional layers is $50^{\circ}$ towards $96^{\circ}$ and the plunge of the lineations is $40^{\circ}$ towards $96^{\circ}$ (figures $1 \mathrm{~b}, 1 \mathrm{c}$ ). The layers vary in thickness from a few $\mathrm{mm}$ to $\mathrm{cm}$, and show pinch-and-swell structures. Individual minerals inside the layers are commonly layer-parallel on both longitudinal (parallel to long axis of the mineral) (figure 2a) as well as transverse sections (section perpendicular to lineation) (figure 2b). This planar fabric has been designated as ' $\mathrm{C}$ '. In rare instances an oblique fabric (S), marked by hornblende and biotite grains, occurs between two adjoining C-planes on longitudinal sections (figure 2a). Collectively these define the magmatic S-C fabric in the rock. The reason for naming the fabric as S-C fabric similar to that of ductile shear zones will be discussed later. In many instances the compositional layers are folded (figure 2c) into symmetrical to asymmetrical, isoclinal to open, steeply plunging to reclined folds with near Class 2 geometry (Ramsay 1967). The folds show variable wavelength and amplitude even in the layers having similar composition and thickness. They have been converted to sheath folds in places. The axial planes of the folds dip to ESE and in most instances the axes show moderate to steep plunge in NNE-SSW direction or towards ESE. In the asymmetrical folds the sense of overturning is towards NW. The hinge zone of the fold exhibits an axial planar arrangement of biotite, hornblende and feldspar grains (figure 2c). Mineral lineations parallel to the hinge line of the folds are developed due to linear arrangement of biotite, hornblende and feldspar grains. They appear almost down dip on the compositional layers. Boudinage structure is occasionally observed in compositional layers; amphibolite-schlieren is asymmetrically folded with northwesterly vergence and, agmatic structure is observed due to segregation of mafic minerals around feldspar pockets.

\subsection{Host rock}

Regional host rock structures are important for understanding the emplacement mechanism and the strain field at the time of emplacement. Amongst all, the granitic mylonite acts as an ideal host rock for understanding the kinematics of the TBSZ. The mylonites are marked by mylonitic foliation, stretching lineation, S-C fabric, and sigmoidal porphyroclasts that unequivocally point to NW vergence of thrusting of the EGMB over the Bastar Craton (Biswal et al 2000). The mylonitic foliations show $45^{\circ}$ dip towards $92^{\circ}$ while the stretching lineations plunge $40^{\circ}$ towards $94^{\circ}$ (figures $1 \mathrm{~d}, 1 \mathrm{e}$ ). These orientations are strictly concordant with those of the compositional layers and mineral lineations in the nepheline syenite plutons (figures 1b, 1c). In many instances, asymmetric folds with NW overturning are observed in the amphibolites of the TBSZ on a scale too small to map. An 'S' shaped fold developed on the contact between amphibolite and nepheline syenite near Durkamura is an example of such large scale fold. The nepheline syenite plutons have earlier been described to contain similar asymmetrical folds. In addition to these folds, the southernmost nepheline syenite and the surrounding host rock show a broad 

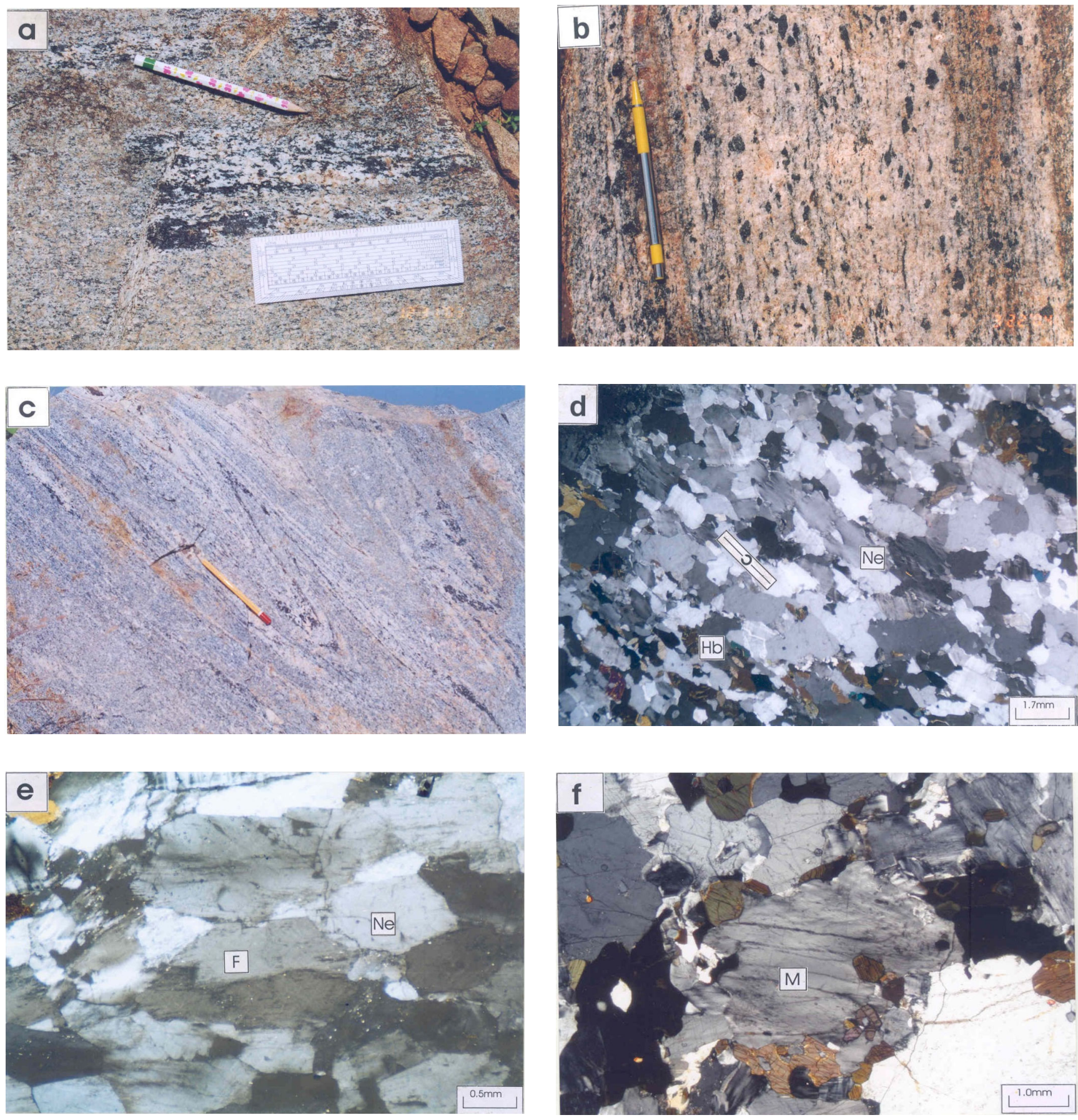

Figure 2. (a) (figure to be rotated $90^{\circ}$ anticlockwise) longitudinal section (nearly vertical, looking towards NE) of nepheline syenite shows magmatic foliation (scale parallel) defined by alternate feldspar+nepheline, and biotite+hornblende layers. Magmatic foliation represents the C-fabric. In addition, an oblique fabric is visible, (pencil parallel) which is called S-fabric. Together they constitute the magmatic S-C fabric in the rock; (b) Transverse section (near horizontal) showing magmatic foliation (pencil parallel); (c) Magmatic folds, the hornblende grains are at high angle to layers at the hinge. (d) Hypidiomorphic texture of nepheline syenite. Magmatic layers (marked as $\mathrm{C}$ ) defined by concentration of hornblende (Hb) and feldspar-nepheline grains (Ne) in layers; (e) Lath shaped feldspar (F) and hexagonal nepheline (Ne) grains show well-developed crystal faces on longitudinal section; (f) Porphyritic texture with microcline phenocrysts (M) being surrounded by smaller microcline and hornblende grains.

warp near Uparpita which has been explained as a fault-induced fold developed over the lateral ramp structure of the TBSZ (Biswal and Sinha 2003).

\section{Microstructures}

The plutons and the host rock display the following microscopic structures. 


\subsection{Nepheline syenite}

The nepheline syenite is a coarse-grained rock consisting of perthitic microcline, orthoclase, nepheline, biotite, hornblende and aegirine as major minerals and albite, calcite, apatite, zircon and sphene as accessories. The rock predominantly shows a hypidiomorphic granular texture with well-developed crystal faces in most of the minerals (figures 2d, 2e). Occasionally, porphyritic texture is observed due to the presence of small microcline and other minerals around microcline phenocrysts (figure 2f) and poikilitic texture is seen with hornblende phenocrysts enclosing smaller grains of feldspars. Perthite structure is very common in the rock defined by flame-type albite lamellae inside K-feldspars. In addition, albite rims occur around feldspar grains in many instances (figure 3a). The rims share a cuspate-lobate interface with the core feldspar grains. Apart from these, cuspate-lobate margins are also seen in other feldspar grains which are not having any such rims. Though the feldspar grains are commonly straight, in some of the sections, they show arcuate geometry and are tiled up in an imbricate fashion (figure $3 b$ ). The majority of the minerals in nepheline syenite show uniform extinction, feldspars show straight twin lamellae and hornblende and biotite flakes lack any kind of kink on their cleavage. Thus it has been inferred that the minerals are predominantly of magmatic origin and have not undergone solid state deformation. The minerals are most distinctively segregated into layers. Biotite, hornblende and aegirine-rich layers are thin and alternate with thick microcline, albite and nepheline-rich layers. The long axes of the individual minerals are oriented parallel to such layers (figure $2 \mathrm{~d}$ ). The layers represent the magmatic foliations in the rock and have been referred to as C. Additionally, biotite and hornblende grains, in few instances, occur obliquely to the $\mathrm{C}$ fabric and thus define the S-fabric (figure 3c). These together form the magmatic S-C fabric in the rock.

Magmatic fabric is superimposed by solid state deformation fabric in various scales. In the central part of the plutons, a small fraction of the minerals shows undulose extinction that coexists with grains free from undulose extinction, whereas discrete shear fractures are developed parallel to the magmatic foliation at the margin of the plutons and in the quartz syenite (figure 3d). Rare quartz and feldspar ribbons with strong undulose extinction occur parallel to the shear fractures. Feldspar, quartz and biotite have undergone dynamic recrystallization along these fractures. Strain induced myrmekitic structure is developed at the margin of the feldspar laths (figure 3e). The dynamically recrystallized grains along the shear fracture are small in size, lensoidal in shape and strain-free. Many of them are oblique to the shear fractures. From the obliqueness of such grains a NW reverse sense of shear is interpreted here for the fractures.

\subsection{Host rock}

The cratonic mylonite shows preservation of a variety of microscopic mylonitic fabrics (Biswal et al 2000). Alternate quartz ribbons, mica bands and feldspar domains define the mylonitic foliation or C-fabric in the rock (figure 3f). Quartz ribbons have undergone dynamic recrystallization into small quartz grains which occur at an angle to C-fabric. These small quartz grains are lensoidal, strain free and exhibit grain shape fabric known as S-fabric. The S-C fabric indicates NW sense of shear. Further, sigmaand delta-type feldspar porphyroclasts, asymmetric folds, asymmetric quartz c-optic axis figure, and mica and quartz fishes are commonly seen in mylonite (Biswal et al 2000). All these features unequivocally suggest reverse slip shear along the TBSZ that is interpreted as the thrusting of EGMB over Bastar Craton. The host rock and nepheline syenite show marked similarity with respect to the orientation of the foliation, lineation and S-C fabric while they differ in the nature of deformation in feldspar. The feldspars in the granitic mylonite have undergone brittle deformation, shear fractures and chemical breakdown to quartz and mica. The feldspars in the nepheline syenite have undergone dynamic recrystallization along discrete shear fractures. This suggests that the solid state deformation in the nepheline syenite has taken place at high temperature, whereas it has occurred at a lower temperature in the granitic mylonite.

\section{Discussion}

Preservation of well-developed crystal faces and absence of dynamic recrystallization are important criteria to distinguish igneous minerals from their metamorphic counterparts. The nepheline syenite plutons in the study area are dominated by euhedral to subhedral grains that lack polygonisation, marginal granulation and dynamic recrystallization (figures 2d, 2e). All these features suggest the magmatic origin of the minerals. However, in certain instances the feldspars show cuspate-lobate margins (figure 3a), a feature commonly associated with solid state deformation. But none of these grains show evidence for such deformation. Therefore, the irregular grain margins could be the result of grain boundary migration induced by residual melt during solidification of the magma (Patterson et al 1998). 

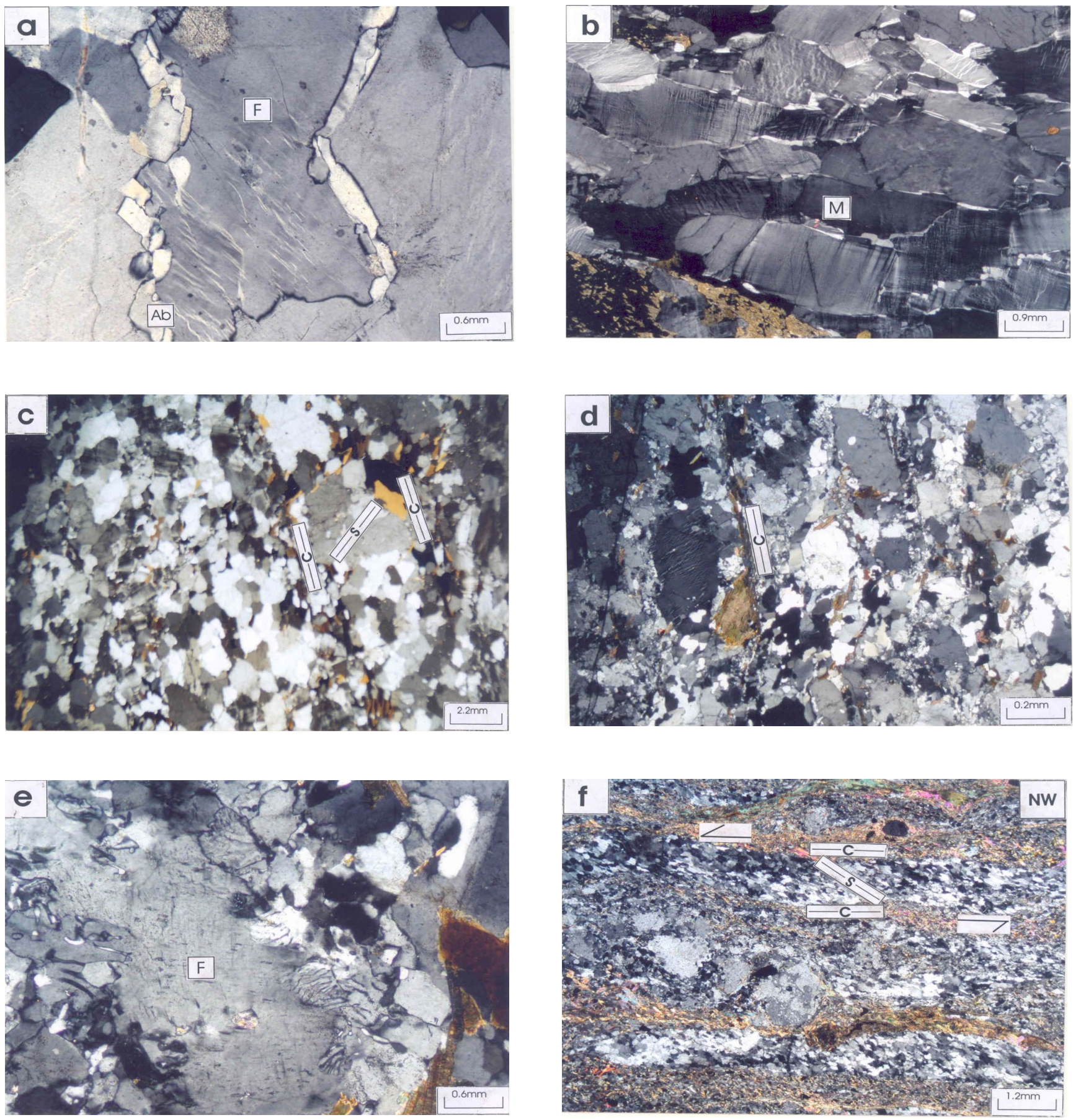

Figure 3. (a) Perthite showing albite lamellae inside host K-feldspar grain (F). The host is surrounded by albitic rim (Ab) which has grown in optical continuity with the inner lamellae; (b) Arcuate geometry of the microcline (M) grains. Other microcline grains are tiled up in imbricate fashion; (c) Magmatic S-C fabric. C-fabric marked by elongation of feldspar laths indicates the flow direction of magma and S-fabric marked by oblique biotite grains indicates the X-axis of the strain ellipsoid in a noncoaxial strain; (d) Solid state deformation in quartz syenite; along discrete shear planes, parallel to magmatic foliation (C), dynamic recrystallization of feldspar has taken place; (e) Feldspar laths show strain induced myrmekitic structures on the border; (f) (to be rotated $90^{\circ}$ anticlockwise) S-C fabric in granitic mylonite. The C-fabric is defined by alternate quartz ribbons filled in with dynamically recrystallized quartz grains and mica rich layers. The S-C fabric suggests reverse slip. The sense of shear is towards NW implying thrusting of the EGMB over the Bastar Craton.

The nepheline syenite plutons are well banded with compositional layers, made up of alternate biotite-hornblende and feldspar rich layers. The minerals are arranged parallel to the layers (figures 2b, 2d) except at the hinge of magmatic folds (figure 2c). As the density contrast of these minerals with respect to the melt differs, mafic (amphibole, pyroxene and biotite) and 
felsic (microcline and nepheline) minerals tend to segregate into layers during flow of the magma, thereby developing compositional layers. The compositional layers thus define the magmatic foliation in the rock. The magmatic foliation parallels the tectonic foliation of the host rock and cuts across the pluton-margin at the tip (coupling, Paterson et al 1998); therefore the emplacement of nepheline syenite magma is inferred to be synkinematic with the regional deformation. Had plutonism been pre- or post-regional strain, the magmatic foliation would have been parallel to the plutonmargin (decoupling). The regional tectonics, as indicated by the mesoscopic structures in the host rock, display a noncoaxial strain. The S-C fabric provides insight into the nature of the incremental strain ellipsoid in the mylonite. The C-fabric denotes the shear plane and S-fabric represents the XY plane of the strain ellipsoid. By comparing the longitudinal and transverse sections of the mylonites the geometry of the incremental strain is assumed to be: X inclined towards NW, Y horizontal and parallel to strike of the C-fabric, and Z perpendicular to XY plane (figure 1f). The slip plane (C-fabric) is the fabric attracter in a noncoaxial strain (Passchier and Trouw 1996). Hence the minerals in the crystal-melt-mush, which is emplaced in a noncoaxial strain regime, tend to align parallel to the C-fabric of the host rock. Thus a magmatic foliation develops in the pluton concordant with the surrounding tectonic foliation (figures $1 \mathrm{~b}$, 1d) and the magmatic foliation is referred to as Cfabric. The external stress field was absorbed by the melt and hence the grains retained their undeformed, magmatic identity. The minerals that are subsequently crystallized inside the chamber developed parallel to the XY plane of the strain ellipsoid and rotated towards the C-plane with progressive flow of magma. Those that could not rotate completely due to intervention of neighbouring grains remained oblique to C-fabric. These are therefore referred to as S-fabric. Since the S-fabric develops due to crystallization of minerals along XY plane of the strain ellipsoid in a noncoaxial strain and Cfabric parallel the shear direction, the magmatic S$\mathrm{C}$ fabric in nepheline syenite is comparable with the Type II S-C fabric described by Lister and Snoke (1984).

Complete rotation of crystals is possible when the melt to crystal ratio is high (suspension type) and magma behaves as a Newtonian fluid. The fact that a small fraction of the grains shows a variation in degree of alignment indicates that the nepheline syenite magma had a nonuniform rheology. The magmatic folds present in certain parts of the plutons suggest local Newtonian flow, because they show near Class 2 geometry and have been converted to sheath folds in many instances. There is strict parallelism between the axial planes of the folds and the internal C-fabric (magmatic foliation), and most minerals are aligned parallel to the axial plane, resembling axial planar cleavage. Hence we interpret that the folds are developed not due to layer parallel shortening but due to inhomogeneous flow parallel to the axial plane of the fold.

Features suggestive of higher crystal to melt ratio occur in some part of the plutons. The S-C fabric preserved in some of the sections is the result of inhibition of complete rotation of grains from the XY plane towards the $\mathrm{C}$-fabric due to interference of neighbouring grains. Further, smaller grains that occur in a haphazard fashion in a porphyritic assembly also suggest nonrotation. A spatial variation in rheology of the melt could be due to initial inhomogeneity of the magma. Alternatively, with cooling, the liquid in the magma chamber changes from a suspension- (fewer crystals) to grain-supported flow (more crystals). A few feldspar grains have assumed an arcuate shape and some are tiled up in imbricate fashion (figure 3b). But none of these grains show intracrystalline deformation or fracturing. Thus it is interpreted that the arcuate shape is the result of crystallization of the mineral during flow of magma in a noncoaxial strain regime. Further tiling up of the grains is due to grain boundary slip during flow. Had there been solid state deformation, the minerals would have shown undulose extinction and dynamic recrystallization.

In certain parts of the plutons, particularly along the margin and in quartz syenites, the minerals display intracrystalline plastic strain. But they coexist with grains showing no such strain. In these rocks, discrete shear fractures occur along the longer margin of the feldspar laths parallel to the magmatic foliation. The fractures are marked by ductile deformation as indicated by the formation of feldspar ribbons, dynamic recrystallization of feldspars and undulose extinction in quartz and feldspar. The dynamically recrystallized minerals have grown in an oblique fashion to the shear fractures suggesting noncoaxial strain (figure $3 \mathrm{~d}$ ). The sense of shear is the same as that of the surrounding mylonite. Strain-induced myrmekite structure is developed around corroded K-feldspar (figure 3e) attesting near solidus (Hibbard 1987) or high temperature solid state deformation (Simpson and Wintsch 1989). This may approximately lie in the range of $550^{\circ} \mathrm{C}$ (Tribe and D'Lemos 1996). From these features we conclude that the plutons have experienced a transition from magmatic fabric to solid state deformation fabric (Miller and Paterson 1994) under a noncoaxial strain. The magmatic $\mathrm{S}-\mathrm{C}$ fabric, shear fractures in the peripheral part of the plutons and the shear strain fabric of the 
host mylonite show noncoaxial strain kinematics for their development. This suggests synkinematic emplacement of nepheline syenite during thrusting. The incremental shear strain during which the magmatic fabrics were formed was absorbed by the plutons as they were crystallizing, but still partially molten. The plutons therefore record a small increment of crustal scale strain, a "snapshot", in its geologically brief magmatic state. However, the host rock has undergone a low temperature solid state deformation during thrusting as indicated by the absence of ductile deformation with feldspars in the granitic mylonite. The pressure and temperature would be comparable with greenschist to lower amphibolite facies of metamorphism. Contrarily, the feldspars in nepheline syenite show ductile deformation. Hence it is interpreted that the internal temperature of plutons assisted in such high temperature deformation of feldspars. Thus a continuum of deformation of the plutons and host rock has occurred during emplacement of nepheline syenite magma at different temperature conditions.

$\mathrm{U}-\mathrm{Pb}$ isotopic data for zircons indicate a crystallization age for nepheline syenite as $1500+3 /-4 \mathrm{Ma}$ (Aftalion et al 2000) and Rb$\mathrm{Sr}$ isochron age of $1436 \pm 58 \mathrm{Ma}$ (Sarkar et al 1994). Based on this date, the age of thrusting along TBSZ has been inferred to be ca $1.5 \mathrm{Ga}$ (Biswal et al 2000) that has taken place immediately following the granulite metamorphism.

\section{Acknowledgement}

This project was funded by the Department of Science and Technology, New Delhi. Reviews by Carol Simpson (Brown University, U.S.A.), S P Mohanty (Indian School of Mines, Dhanbad) and Samarendra Bhattacharya (Indian Statistical Institute, Kolkata) are deeply acknowledged.

\section{References}

Aftalion M, Bowes D R, Dash B and Fallick A E 2000 Late Pan-African thermal history in the Eastern Ghats terrane India from U-Pb and $\mathrm{K}-\mathrm{Ar}$ isotopic study of the Mid-Proterozoic Khariar alkali syenite Orissa; Proc. Precambrian Crust in Eastern and Central India IGCP-368 Bhubaneswar (Geol. Surv. Ind. Calcutta) 26-33

Bhattacharya S and Kar R 2002 Alkaline intrusion in a granulite ensemble in the Eastern Ghats Belt India shear zone pathway and crust-mantle linkage; Transport and flow processes in shear zones Abstract Geol. Soc. London 10

Biswal T K 2000 Fold-thrust belt geometry of Eastern Ghats Mobile Belt - a structural study from its western margin Orissa India; J. African Earth Sci. Spl. Issue 31 25-33
Biswal T K, Jena S K, Datta S, Das R and Khan K 2000 Deformation of the Terrane Boundary Shear Zone (Lakhna shear zone) between the Eastern Ghats Mobile Belt and the Bastar Craton in the Balangir and Kalahandi districts of Orissa; J. Geol. Soc. India 55 $367-380$

Biswal T K, Biswal B, Mitra S and Roy Moulik M 2002 Deformation pattern of the NW terrane Boundary of the Eastern Ghats Mobile Belt India: A Tectonic Model and Correlation with Antarctica; Gond. Res. 51 45-52

Biswal T K and Sinha S 2003 Deformation history of the NW salient of the Eastern Ghats Mobile Belt India; J. Asian Earth Sci. 22 157-169

Bose M K 1970 Petrology of the intrusive alkalic suite of Koraput Orissa; J. Geol. Soc. India 11 99-126

Bouchez J L, Gleizes G, Djouadi T and Rochette P 1990 Microstructure and magnetic susceptibility applied to emplacement kinematics of granites, the example of Foix pluton (French Pyrenees); Tectonophysics 184 $157-171$

Hibbard M J 1987 Deformation of incompletely crystallized magma systems granitic gneisses and their tectonic implications; J. Geol. 95 543-561

Leelanandam C 1993 Alkaline Magmatism in the Eastern Ghat Belt - A Critique; J. Geol. Soc. India 42 435-447

Lister G S and Snoke A W 1984 S-C mylonites; J. Struct. Geol. 6 617-638

Madhavan V and Khurram M Z A K 1989 The Alkaline Gneisses of Khariar Kalahandi District Orissa; Mem. Geol. Soc. India 15 265-289

Miller R B and Paterson S R 1994 The transition from magmatic to high-temperature solid-state deformation implications from the Mount Stuart batholith Washington; J. Struct. Geol. 16 853-865

Panda P K, Patra P C, Patra R N and Nanda J K 1993 Nepheline Syenite from Rairakhol Sambalpur District Orissa; J. Geol. Soc. India 41 144-151

Passchier C W and Trouw R A J 1996 Microtectonics (Springer)

Paterson S R, Fowler T K Jr, Schmidt K L, Yoshinobu A S, Yuan E S and Miller R B 1998 Interpreting magmatic fabric patterns in plutons; Lithos 44 53-82

Ramakrishnan M, Nanda J K and Augustine P F 1998 Geological evolution of the Proterozoic Eastern Ghats Mobile Belt; Geol. Surv. India. Spl. Publ. 44 1-21

Ramsay J G 1967 Folding and fracturing of rocks (New York: Mc GrawHill)

Ratnakar J and Leelanandam C 1989 Petrology of the alkaline plutons from the eastern and southern Peninsular India; Mem. Geol. Soc. India 15 145-176

Sahu K N 1976 Petrological observations on nepheline syenites of Baradangua Dhenkanal Orissa; J. Geol. Soc. India 17 484-489

Sarkar A, Nanda J K, Sarkar G, Pati U C, Bishui P K and Gupta S N 1994 Rb-Sr geochronology of the Khariar alkaline Complex Orissa Sector Eastern Ghats Belt; Proc.Eastern Ghats Mobile Belt.Visakhapatnam 15-16 June Geol. Surv. India 74-75

Simpson C and Wintsch R P 1989 Evidence for deformationinduced K-feldspar replacement by Myrmekite; J. Met. Geol. 7 261-275

Srinivasachari K and Balakrishnan P 1973 Nepheline syenites of Khariar Kalahandi district Orissa; Abstract volume Symposium on Peninsular Shield (Ind. Acad. Geosci. Hyderabad) 32

Tribe I R and D'Lemos R S 1996 Significance of a hiatus in down-temperature fabric development with syntectonic quartz diorite complexes Channel Islands UK; J. Geol. Soc. London 153 127-138 